\title{
SEDIMENTOLOGY AND MATURITY OF AJALI FORMATION, BENIN FLANK ANAMBRA BASIN, NIGERIA
}

\author{
Ilevbare, M.* and Imasuen O. I. \\ Department of Geology, University of Benin, Benin City, Nigeria \\ "Corresponding Author's Email: ilevbaremartins777@gmail.com +234 8036993220 \\ (Received: 7th February, 2020; Accepted: 6th April, 2020)
}

\section{ABSTRACT}

\begin{abstract}
The Ajali Sandstone, western flank, Anambra Basin, was studied for textural characteristics and maturity of the sediments. Grain size analysis (51 samples), thin section and heavy mineral analysis (15 samples each) and XRF fusion for metallic oxides (15 samples) were analyzed. The textural parameters show that the Ajali Sandstone are medium sand, poorly to moderately sorted, coarse to strongly coarse skewed with mesokurtic to leptokurtic grains. The thin section analysis reveals grains that are sub-angular to sub-rounded (this typifies grains that have travelled fairly long distance to the deposition site), of moderate to well sorted grains, with both monocrystalline and polycrystalline quarts-grains type, with a modal composition of $\mathrm{Q}_{90.4} \mathrm{~F}_{2.3}$ and $\mathrm{L}_{2.9}$. A mineralogical maturity index (MMI) of 17.04, $\mathrm{SiO}_{2} / \mathrm{Al}_{2} \mathrm{O}_{3}$ ratio of 180.24 , and a ZTR index of $67.96 \%$ were obtained. The values for the MMI and $\mathrm{SiO}_{2} / \mathrm{Al}_{2} \mathrm{O}_{3}$ indicates mineralogical matured sediments, the ZTR index shows a chemically immature to sub-mature sandstone, and the modal composition values are consistent with a texturally and compositionally matured sands. The mineralogical maturity is indicative of high degree of chemical weathering of source area. Furthermore, the high quartz and silica content make the sandstone prospective for glass and glassware production.
\end{abstract}

Key words: Anambra Basin, Maturity, Mineralogical maturity index, Textural characteristics, Glass

\section{INTRODUCTION}

An integration of multidisciplinary tools involving particle size analysis, mineralogical and geochemical analyses provide a wealth of information on the intrinsic properties of sediments, which is important to elucidate the nature and energy flux of the multifarious agents transporting the sediments (Ramanathan et al.,
2009; Anithamary et al., 2011). This study, investigates the textural characteristics and the maturity of the Ajali Formation, western flank of the Anambra Basin, as well as harmonized the findings from previous researchers with a view to authenticate the maturity and source area weathering that were in operation during transport and deposition of the sediments.

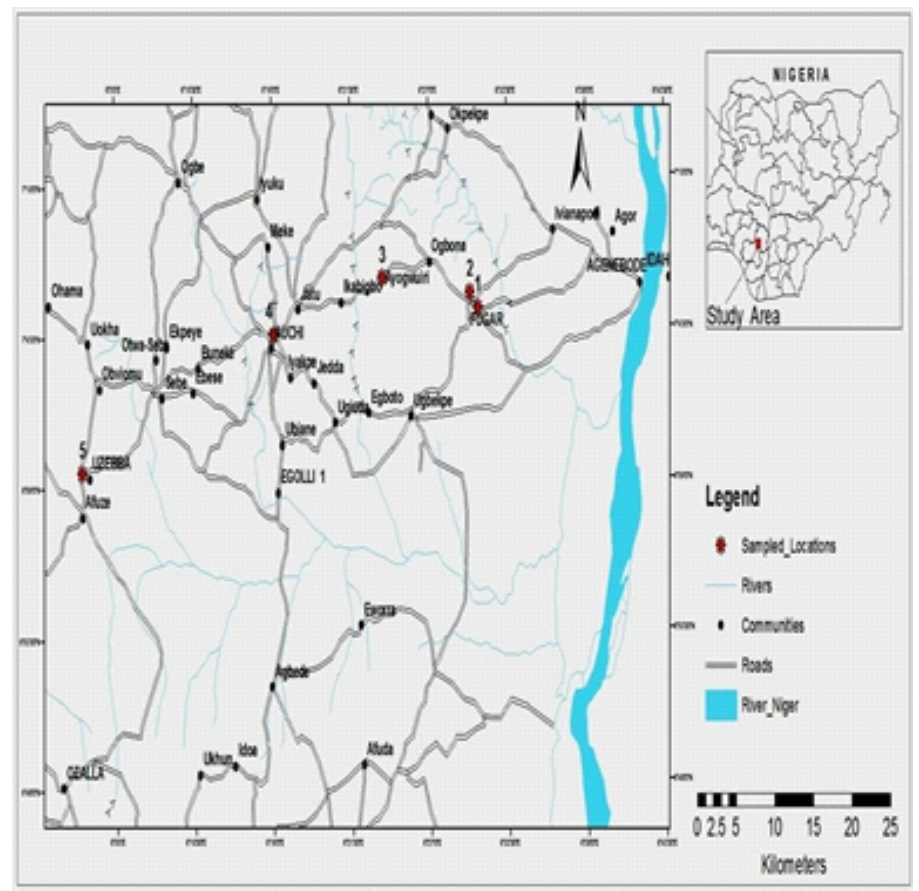

Figure 1: Location Map and Sampling Points in the Study Area 


\section{Location of Study Area}

The study area and its environs are situated in Fugar, Ayogwuiri, Auchi and Uzebba all enclosed within the Ajali Formation. The area is highly accessible with major and minor roads, together with other adjoining roots. The location map (figure 1) was generated using the GPS coordinates obtained from the field studies.

\section{Geologic Overview}

The Anambra Basin (Figure 2) represents the sag phase of the Benue Trough evolution. It formed in response to thermal induced basin subsidence west of the Southern Benue Trough after the Santonian inversion episode (Reijers et al., 1997). Its basin fill comprises of the Nkporo Group, the Mamu Formation, the Ajali Formation and the Nsukka Formation in stratigraphic order

The Ajali Formation is characteristically cross- bedded and friable with a sheet-like configuration (Ladipo 1986; Adekoya et al., 2011; Odumoso et al., 2015). In the western flank of the Anambra Basin, Adekoya et al., (2011) identified three lithofacies, which comprises of bioturbated shale facies, tabular cross-bedded sand facies and ferruginous sand facies. Ladipo (1986) opined that the ferruginization is post-depositional. Previous studies have provided contradictory descriptions of the Ajali Formation sands. Whereas Hoque (1977), Akpofure and Etu-Efeotor (2013), Gideon et al. (2014), Odumoso et al. (2015), reported fine to coarse grained, moderately to poorly sorted, subangular to subrounded grain textures. Amajor (1987) described the Ajali sandstone as predominantly sub-rounded to wellrounded with fairly good sorting. Despite this, published data report very high amount of quartz, implying mineralogical maturity (Akaegbobi et al., 2001; Akpofure and Etu-Efeotor (2013)

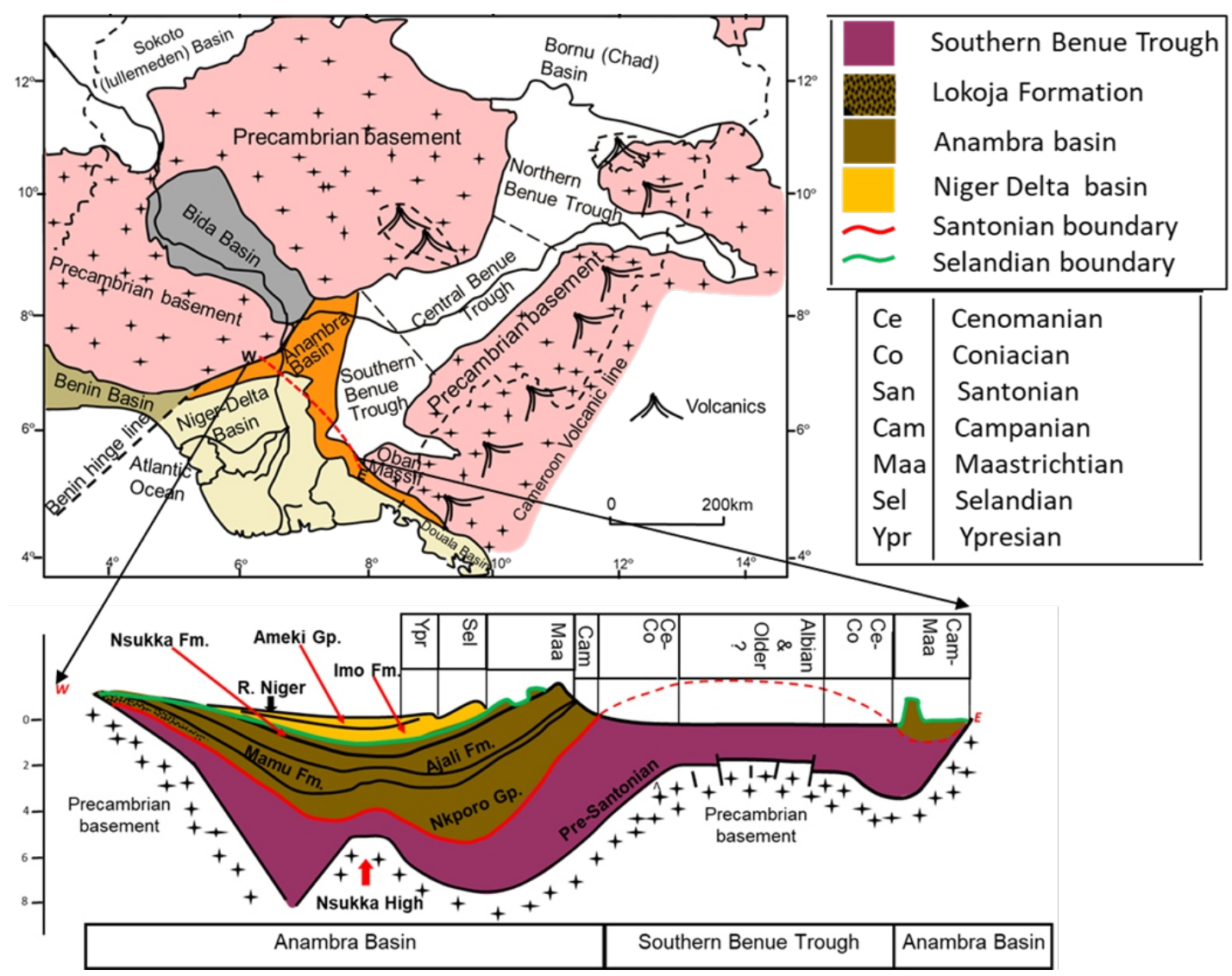

Figure 2: Map of Nigeria showing areas underlain by basement and sedimentary rocks. Below is a W-E cross-section of the Anambra Basin and Southern Benue Trough (Edegbai et al., 2019) 


\section{MATERIALS AND METHOD Sample Collection}

Samples were collected at an interval of $0.6 \mathrm{~m}$ in 5 different locations underlain by the Ajali Formation in the Benin flank. In all, 51 samples were collected. A total of 25 samples each were analysed for heavy mineral and thin section analysis (5 samples from each location), 15 samples for XRF analysis (3 samples from each location) and 51 samples for grain size analysis. The sample locations are Fugar (FG, 17 samples), Fugar II (FGB, 12 samples), Ayogwuiri (AY, 10 samples), Auchi (AU, 7 samples) and Uzebba (UZ, 5 samples).

\section{Grain Size Analysis}

$50 \mathrm{~g}$ was weighed and mechanically sieved at the Sedimentology laboratory of the Department of Geology, University of Benin, Nigeria. Mean, sorting, skewness and kurtosis (grain size parameters) were thereafter computed from the recorded weight percentages of the sieves and pan.

\section{Mineralogical analysis}

25 samples each (5 samples per location) were selected for thin section and heavy mineral analyses.

\section{Thin Section Analysis}

The samples were air dried for 24 hours, and then impregnated with epoxy and subsequently left to cure for 24 hours. The cured sample was trimmed to fit on a glass slide, and the sample smoothened using water and silicon carbide (600 grits) on a glass plate. The samples were thereafter bonded to the glass slide using epoxy on the hot plate for 24hours, trimmed to 50micron and lapped to 30 micron using silicon carbide and water. Mineral identification and textural analysis, point counting of mineral grains were carried out on the slides using a transmitted light microscope at the Sedimentology laboratory of the Department of Geology, University of Benin.

\section{Heary Mineral Analysis}

The experimental procedure entailed pouring $5 \mathrm{~g}$ of air-dried sample into an already mounted separating funnel filled to $3 / 4$ of its volume with bromoform. The heavy minerals contained in the samples which sunk to the bottom of the funnel was collected in a filter paper, washed with acetone to remove all the bromoform, and mounted on a clean glass slide using DPX mountant. Mineral identification and textural analysis, point counting of mineral grains were carried out on the slides using a transmitted light microscope at the Sedimentology laboratory of the Department of Geology, University of Benin

\section{Geochemical analysis (XRF)}

One gram $(1.00 \mathrm{~g})$ of prepared samples was weighed in porcelain and placed in oven at about $110^{\circ} \mathrm{C}$ for 1 hour in order to determine $\mathrm{H}_{2} \mathrm{O}^{+}$. It was further subjected to a temperature $1000^{\circ} \mathrm{C}$ in an oven for about an hour in order to determine loss of Ignition (LOI). Ten grams $(10.00 \mathrm{~g})$ of claisse flux was added and fused in M4 Claisse fluxer for 23minutes. Furthermore, $0.2 \mathrm{~g}$ of sodium trioxocarbonate IV $\left(\mathrm{Na}_{2} \mathrm{CO}_{3}\right)$ was added to the mix; the resulting mix was pre-oxidized at $700^{\circ} \mathrm{C}$ and then fused

\section{RESULTS AND DISCUSSION}

The results of the particle size, mineralogical and geochemical analyses are presented in Tables 1-5.

\section{Textural Analysis:}

The grain size parameters at Fugar (Tables' 1-2), reveal the sands as dominantly moderately sorted, medium grained sandstone. Bulk of the samples are fine to coarse skewed, as well as Mesokurtic to Leptokurtic. At Fugar II (Tables' 1-2), the sandstone are mainly moderately well sorted are medium grained sandstone. Bulk of the samples are coarse to strongly coarse skewed as well as Mesokurtic to Leptokurtic. At Ayogwuiri (Tables' $1-2)$, the sandstone are dominantly medium grained with poor to moderate sorting, coarse to strongly coarse skewed and mesokurtic. At Uzebba (Tables' 1-2), the sandstone are fine grained, moderately well sorted to moderately sorted, strongly coarse skewed, and leptokurtic. The sandstone at Auchi (Tables' 1-2) are medium grained, moderately sorted strongly fine skewed, mesokurtic to leptokurtic. This findings agree with published data (Hoque (1977), Akpofure and Etu-Efeotor (2013), Gideon et al. (2014), Odumoso et al. (2015).

Altogether, the mean, sorting, skewness and 
kurtosis of Ajali Sandstone averages 1.4, 0.87, 0.104 and 1.344 respectively (Table 1), and indicates moderately sorted medium sand, near symmetry with Leptokurtic grain. Folk (1965), classified sorting values as; (1-3) $\phi$ for sand class; $(0.25-0.5) \phi$ for beach sand and (0.35-1.0) $\phi$ for Fluviatile / shallow marine sand. Therefore, the
Ajali Sandstone, is of fluvial origin. Discriminant plots of grain size parameters (Fig. 3-5) which reflect differences in the fluid flow mechanism of sediment transportation and deposition further indicates intermediate energy of transporting and depositional medium which is typical of fluvial environment (Sutherland, 1994).

Table 1: Grain size, parameters of all five (5) locations, showing minimum, maximum and average values of grain size parameters.

Note: $F G=$ Fugar, $F G B=$ Fugar II, $A Y=$ Ayogwuiri, $U Z=U$ zebba and $A U=A$ uchi

\begin{tabular}{|ll|l|l|l|l|}
\hline Area & & Mean $\phi$ & Sorting $\phi$ & Skewness $\phi$ & Kurtosis $\phi$ \\
\hline FG & Max & 1.7 & 1.5 & 0.464 & 3.280 \\
& Min & 0.3 & 0.3 & 0.0625 & 0.801 \\
& Average & 1.0 & 0.9 & 0.263 & 2.041 \\
FGB & Max & 2.0 & 0.8 & 0.193 & 1.50 \\
& Min & 0.7 & 0.5 & -0.083 & 0.81 \\
& Average & 1.35 & 0.65 & 0.055 & 1.155 \\
AY & Max & 1.5 & 1.2 & 0.253 & 1.230 \\
& Min & 0.4 & 0.8 & -0.0717 & 0.934 \\
& Average & 0.95 & 1.0 & 0.0907 & 1.082 \\
UZ & Max & 2.3 & 1.5 & 0.14 & 1.639 \\
& Min & 1.7 & 0.3 & -0.06 & 1.03 \\
& Average & 2.0 & 0.9 & 0.04 & 1.335 \\
AU & Max & 2.3 & 1.1 & 0.216 & 1.27 \\
& Min & 1.2 & 0.7 & 0.071 & 0.94 \\
Average & 1.75 & 0.9 & 0.0725 & 1.105 \\
\hline
\end{tabular}

Table 2: Summary of grain size parameters in percentage of the total number of each Sector

CS- Coarse Sand, MS-Medium Sand, FS-Fine Sand, WS- Well Sorted, MWS-Moderately Well Sorted, MS-Moderately Sorted, PS-Poorly Sorted, VWS-Very Well Sorted, SFS-Strongly Coarse Skewed, PKPlatykurtic, MK-Mesokurtic, LK-Leptokurtic, VLK-Very Leptokurtic, ELK-Extremely Leptokurtic.

\begin{tabular}{|c|c|c|c|c|c|}
\hline & $\mathrm{FG}$ & FGB & AY & UZ & $\mathrm{AU}$ \\
\hline \multicolumn{6}{|c|}{ Mean $\phi$} \\
\hline CS & 22.99 & 9.47 & 3.175 & 0 & 0 \\
\hline MS & 77.02 & 78.69 & 96.83 & 16.10 & 78.94 \\
\hline FS & 0 & 11.84 & 0 & 88.90 & 21.06 \\
\hline \multicolumn{6}{|c|}{ Sorting $\phi$} \\
\hline WS & 6.41 & 0 & 0 & 0 & 0 \\
\hline MWS & 13.93 & 78.93 & 0 & 40.66 & 11.17 \\
\hline MS & 68.36 & 21.07 & 36.22 & 50.38 & 71.68 \\
\hline PS & 11.31 & 0 & 63.78 & 0 & 17.16 \\
\hline VWS & 0 & 0 & 0 & 8.96 & 0 \\
\hline \multicolumn{6}{|c|}{ Skewness $\phi$} \\
\hline SFS & 13.10 & 0 & 16.98 & 0 & 47.37 \\
\hline FS & 39.30 & 0 & 0 & 0 & \\
\hline NS & 7.89 & 25.69 & 0 & 13.73 & 25.87 \\
\hline CS & 37.10 & 52.68 & 30.39 & 17.65 & 0 \\
\hline SCS & 2.49 & 21.61 & 52.62 & 68.63 & 26.75 \\
\hline \multicolumn{6}{|c|}{ Kurtosis $\phi$} \\
\hline PK & 7.43 & 5.83 & 0 & 0 & 0 \\
\hline MK & 39.24 & 48.30 & 76.47 & 15.26 & 51.04 \\
\hline LK & 22.50 & 45.87 & 23.54 & 60.45 & 48.96 \\
\hline VLK & 15.78 & 0 & 0 & 24.29 & 0 \\
\hline ELK & 15.04 & 0 & 0 & 0 & 0 \\
\hline
\end{tabular}




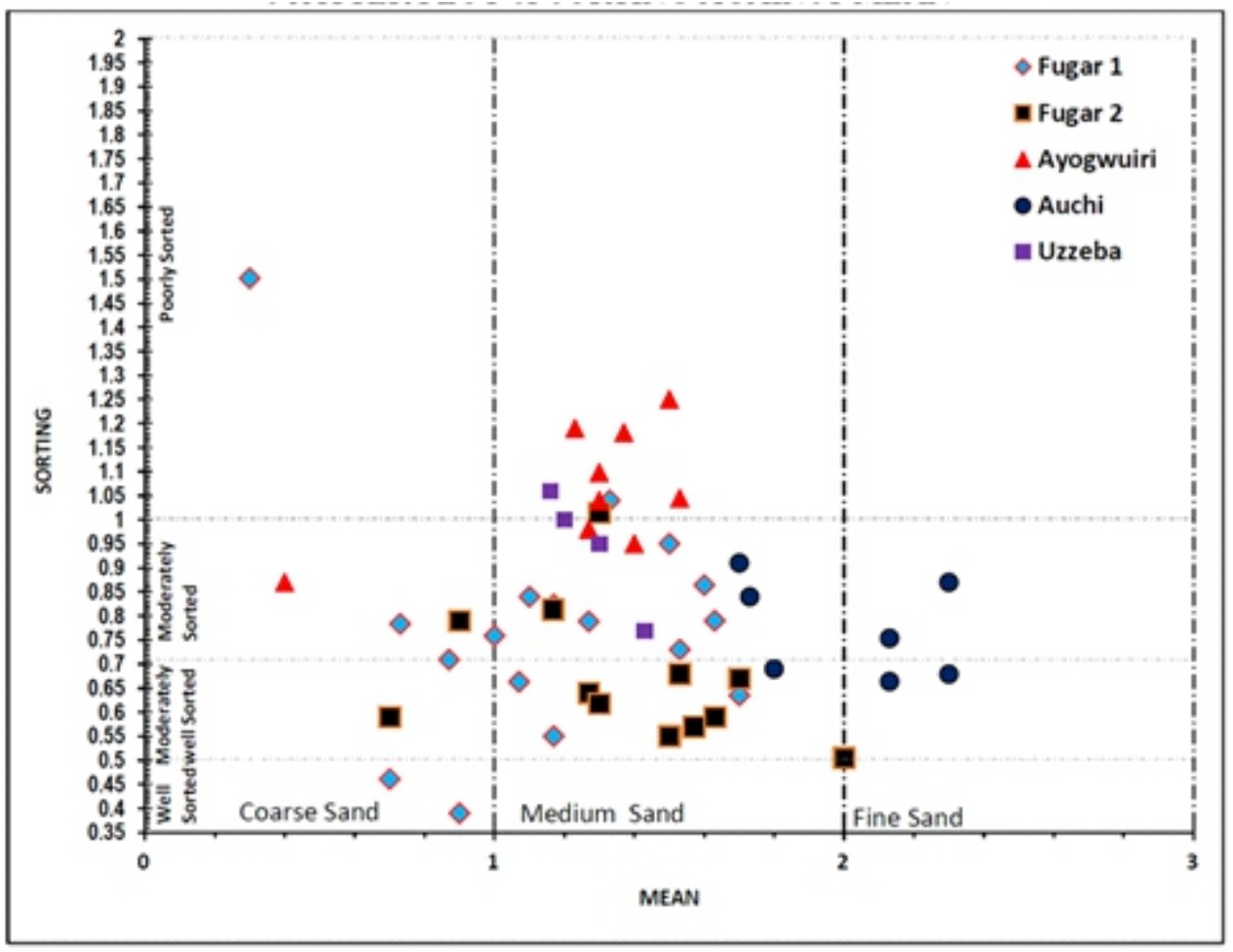

Figure 3: Bivariate relationship between the grain size (phi) and sorting

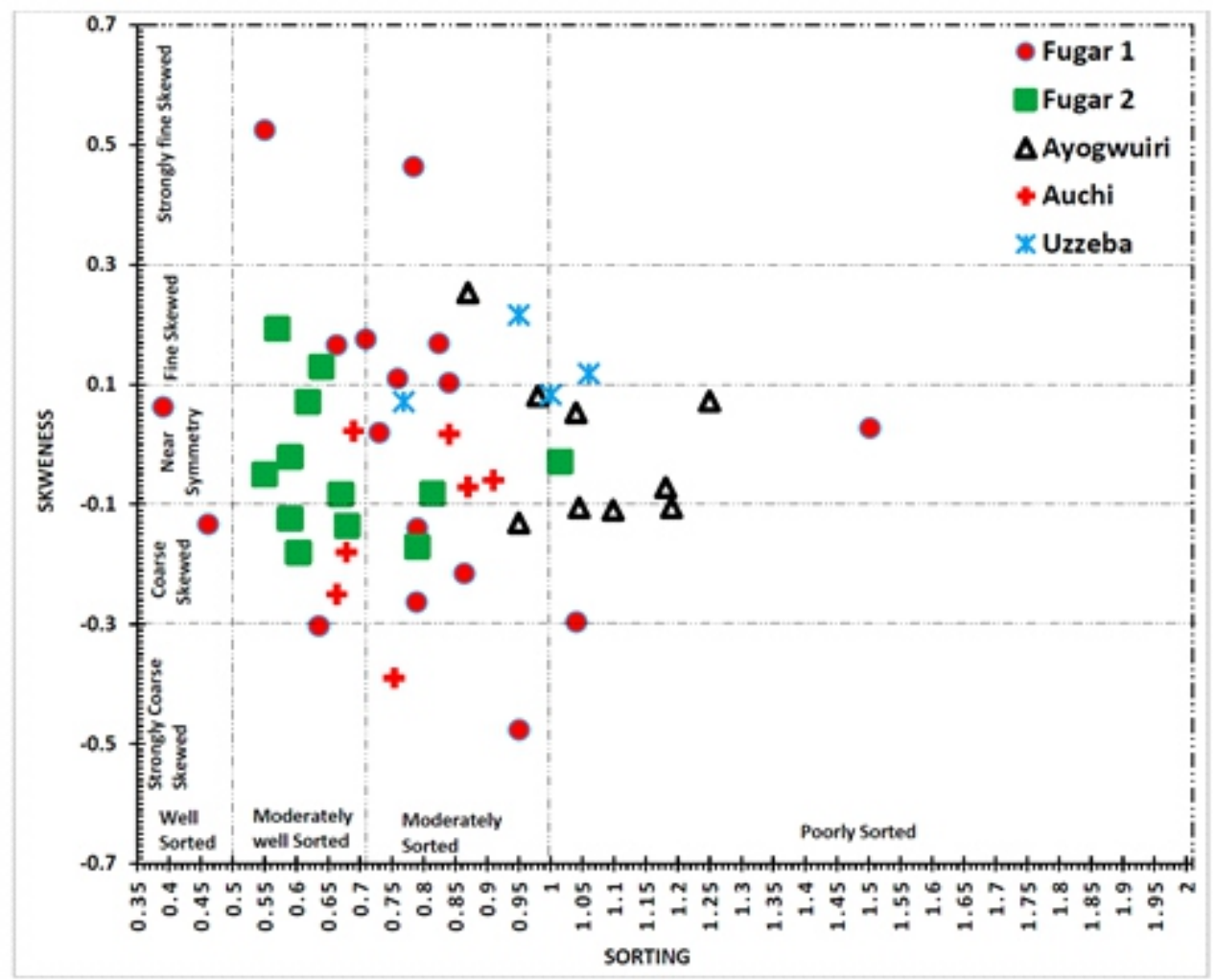

Figure 4: Bivariate relationship between skewness and sorting 


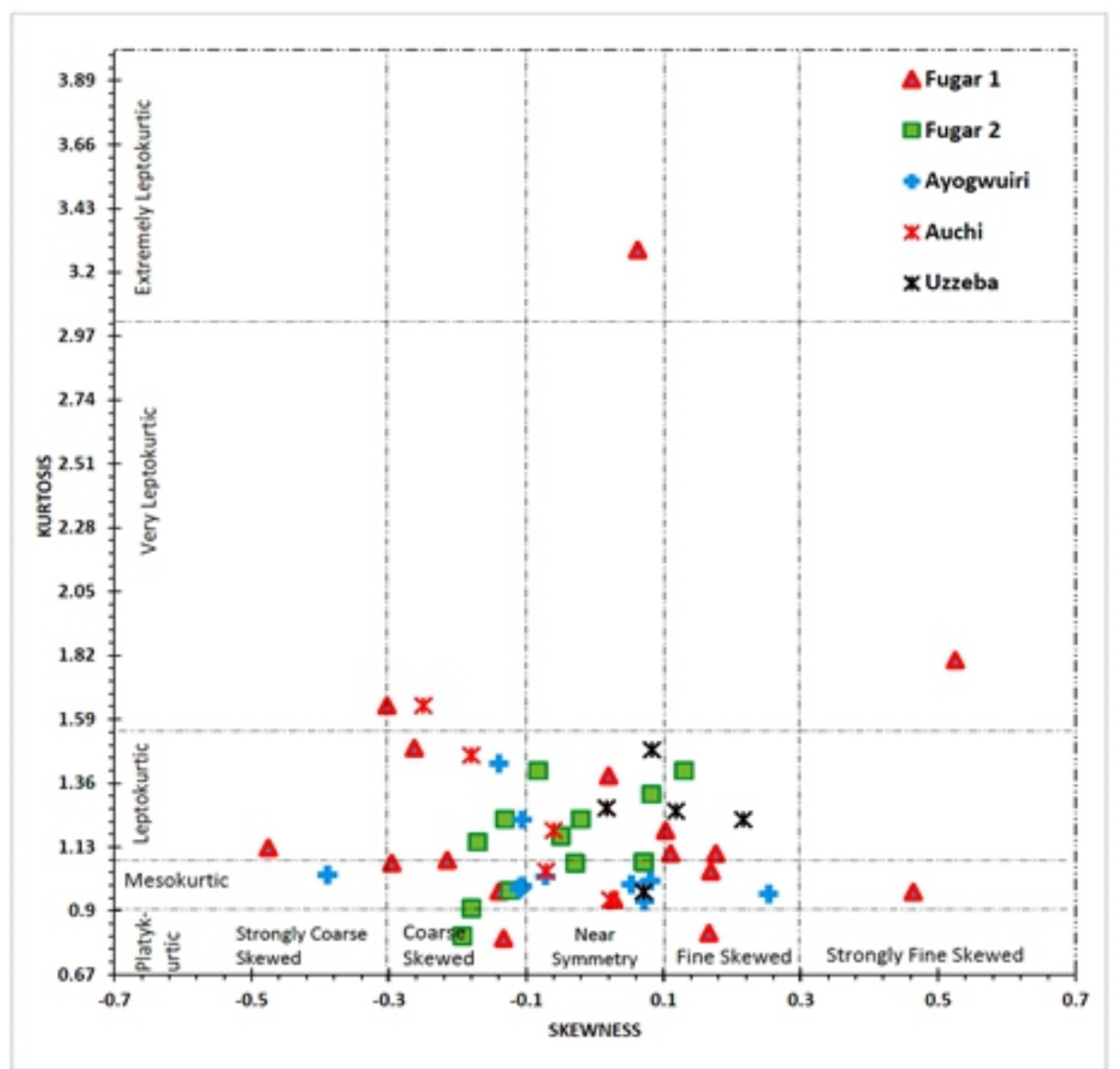

Figure 5: Bivariate relationship between kurtosis and skewness

\section{Sediment Maturity}

Extremely high or low kurtosis values is an indication of different sources for the sediment and most likely from high energy environment. The differences in the values for kurtosis (Table 2, Fig. 5) reflect the flow characteristics of the deposition medium. (Baruah et al., 1997; Ray et al., 2006). The dominance of the mesokurtic and leptokurtic nature of sediments reflects compositionally and mineralogically mature sand. Thin section analysis show quartz as the dominant mineral phase (quartz averages $90.4 \%$, while mineralogical maturity index averages $17.04 \%$ ) in all the samples (Plate 1-2, Table 3-4) implying that the samples are mineralogically mature arenitic sands. This is in agreement with earlier works in other parts of the Basin (Nwajide and Hoque (1985). The samples are dominated by $\mathrm{SiO}_{2}$ which ranges from $95.0 \%$ to $99.5 \%$ (average $=98.24 \%$ ), whereas the $\mathrm{Al}_{2} \mathrm{O}_{3}$ ranges from $0.2 \%$ to $3.0 \%$ (average $=0.79 \%$ ). $\quad \mathrm{Fe}_{2} \mathrm{O}_{3}$ (average $0.47 \%$ ) and $\mathrm{TiO}_{2}$ (average $0.31 \%$ ) low. The high $\mathrm{SiO}_{2} / \mathrm{Al}_{2} \mathrm{O}_{3}$ further confirms the arenitic nature and the mineralogical maturity of the sandstone Potter (1978). In addition, the proportion of polycrystalline quartz is more than monocrystalline quartz (Table 4). This is suggestive of a significant detrital contribution from silica rich metamorphic rocks, thus implying less contribution from older pre-Santonian rocks. Furthermore, heavy mineral analysis reveals the presence of zircon, tourmaline, rutile, staurolite, garnet, kyanite as well as opaques. An average ZTR index of $67.96 \%$ suggests that the samples are submature (Manger and Maurer, 1992). In general, textural analysis reveal that the mineral grains have travelled some distance, implying mature to submature textural maturity (Table 4). The Auchi and Ayogwuiri samples are the exception as they are texturally immature.

\section{Depositional Setting}

Sedimentologist have attempted to use scatter graphs of grain size parameters to distinguish between different depositional setting using bivariate plot (Figure 3-5) which are based on the assumption that the statistical parameters 
reliability reflect differences in the fluid flow mechanism of sediment transportation and deposition (Sutherland and Lee, 1994).

Figure 3, shows that there is clustering in medium sized, moderately sorted to moderately well sorted. The result of bivariate plots indicates intermediate energy of transporting and depositional medium which is typical of fluvial environment.

Figure 4, shows the relationship between sorting and skewness for the Ajali sediments. The Sandstone is both positively and negatively skewed. Positive skewness characterizes a beach with deposition of sand, whereas negative skewness indicates erosion and non-deposition (Akofure and Akane, 2019).

The data points cluster in the near symmetry to coarse skewed region which indicates environments where the effect of erosion and deposition are almost balanced.

Friedman (1961), found that dune sand are generally positive skewed and could be barrier island, coastal lake or fluvial environment while beach sand are found to be negatively skewed.

The plot of Kurtosis against Skewness (Figure 5) is a very powerful tool for interpreting the genesis of sediment by quantifying the degree of Normality of its size distribution (Folk, 1966). The plot (Figure 5) shows that the Ajali sediments lie within the mesokurtic to leptokurtic range. Friedman, (1962) showed that most sands are leptokurtic and are either positively or negatively skewed, extreme high or low values of kurtosis indicate that some of the sediments achieved sorting elsewhere in a high energy environment. Therefore platykurtic to very platykurtic and leptokurtic to very leptokurtic sediments are due to extremely low and high energy environment respectively (Dora et al., 2011). The result obtained from figure 5 is mesokurtic to leptokurtic, it therefore indicates that the Ajali sediments were deposited during intermediate to high energy environment.

\section{Weathering of Source Area}

The dominance of quartz, and low feldspar content as well as the low concentration of $\mathrm{Fe}_{2} \mathrm{O}_{3}$ (average $=0.47 \%$ ), $\mathrm{Al}_{2} \mathrm{O}_{3}$ (average $=0.79 \%$ ) and $\mathrm{TiO}_{2}$ (average $=0.31 \%$ ) maybe attributed to sediment recycling and high degree of chemical weathering of source area. This is consistent with existing Maastrichtian paleoclimate model of Nigeria (Chumakov et al. in Hay and Floegel, 2012) as well as data from Mamu Formation on the Benin flank (Edegbai et al., 2019).

Table 3: Modal composition of sandstone facies studied and mineralogical maturity

\begin{tabular}{|l|l|l|l|l|l|l|}
\hline $\begin{array}{l}\text { Sample } \\
\text { ID }\end{array}$ & $\begin{array}{l}\text { Quartz } \\
\text { (Qtz) }\end{array}$ & $\begin{array}{l}\text { Feldspar } \\
\text { (FSP) }\end{array}$ & $\begin{array}{l}\text { Rock (lithic) } \\
\text { Fragment (RF) }\end{array}$ & $\begin{array}{l}\text { FSP } \\
+ \\
\text { RF }\end{array}$ & MMI & $\begin{array}{l}\text { Mineralogical } \\
\text { maturity index } \\
\text { (MMI) }\end{array}$ \\
\hline FG2 & 90 & 2 & 3 & 5 & $90 / 5$ & 18 \\
FG10 & 90 & 3 & 3 & 6 & $90 / 6$ & 15 \\
FG16 & 91 & 2 & 2 & 4 & $91 / 4$ & 22.75 \\
FGB3 & 89 & 3 & 3 & 6 & $89 / 6$ & 14.83 \\
FGB7 & 91 & 2 & 3 & 5 & $91 / 5$ & 18.2 \\
FGB12 & 92 & 2 & 3 & 5 & $92 / 5$ & 18.4 \\
UZ1 & 90 & 3 & 4 & 7 & $90 / 7$ & 12.86 \\
UZ3 & 91 & 2 & 3 & 5 & $91 / 5$ & 18.2 \\
UZ5 & 90 & 3 & 2 & 5 & $90 / 5$ & 18 \\
AY1 & 90 & 2 & 3 & 5 & $90 / 5$ & 18 \\
AY5 & 90 & 3 & 3 & 6 & $90 / 6$ & 15 \\
AY9 & 91 & 2 & 3 & 5 & $91 / 5$ & 18.2 \\
AU1 & 91 & 3 & 3 & 6 & $91 / 6$ & 15.26 \\
AU4 & 90 & 2 & 3 & 5 & $90 / 5$ & 18 \\
AU6 & 90 & 3 & 3 & 6 & $90 / 6$ & 15 \\
Average & 90.4 & 2.3 & 2.9 & 5.4 & & 17.04 \\
\hline
\end{tabular}


Table 4: Mineral Maturity of Ajali Sandstone Studied

\begin{tabular}{|l|l|l|}
\hline Nwajide and Hoque (1985) & Percentage Range (\%) & This Study \\
\hline Quarts & $95-90$ & 90.40 \\
F + RF & $5-10$ & 5.40 \\
MMI & $19-9.0$ & 17.04 \\
Maturity & Mature & Mature \\
\hline
\end{tabular}

Therefore, Ajali Sandstone following Nwajide and Hoque (1985) mineral maturity classification scheme is mineralogically mature from the result of table 4.

\section{Economic Potential of the Sandstone}

The suitability of quartz sand for different industrial application is determined by the quality of quartz in terms of:

- Grain size distribution. Normally, unprocessed sand may be suitable for a limited range of applications, washing and sizing increases considerably the possible product range.

- Chemical analysis. The grade is determined by the impurities content of the quartz sand and the ground.

- Colour. Very low iron content result in naturally white quartz sands which are preferred for some industrial applications
(BIS: 1988).

In the light of the foregoing, the geochemical analysis of the sands $\left[\mathrm{SiO}_{2}(98.2 \%), \mathrm{TiO}_{2}(0.10 \%)\right.$ and $\left.\mathrm{Al}_{2} \mathrm{O}_{3}(0.63 \%)\right]$ from Table 7 , conforms with the BIS specification for silica industries for glass making and glassware and silica related products (Table 8). The metallic oxide percentages make the Ajali sandstone suited for glass, iron and ceramic industries.

The gross rock volume of the Basin was calculated from the isopach map (figure 5) of the formation and was found to be 1.25 billion $\mathrm{m}^{3}$ (1.25 million $\mathrm{km}^{3}$ ). More so, wells with sandstone bed of $420 \mathrm{~m}$ thick are in the Ajali Formation (sourced from Total Nigeria Ltd., 1988), this thickness is a likely "hot spot" zone for hydrocarbon, mineral exploration and hydrogeological prospecting.

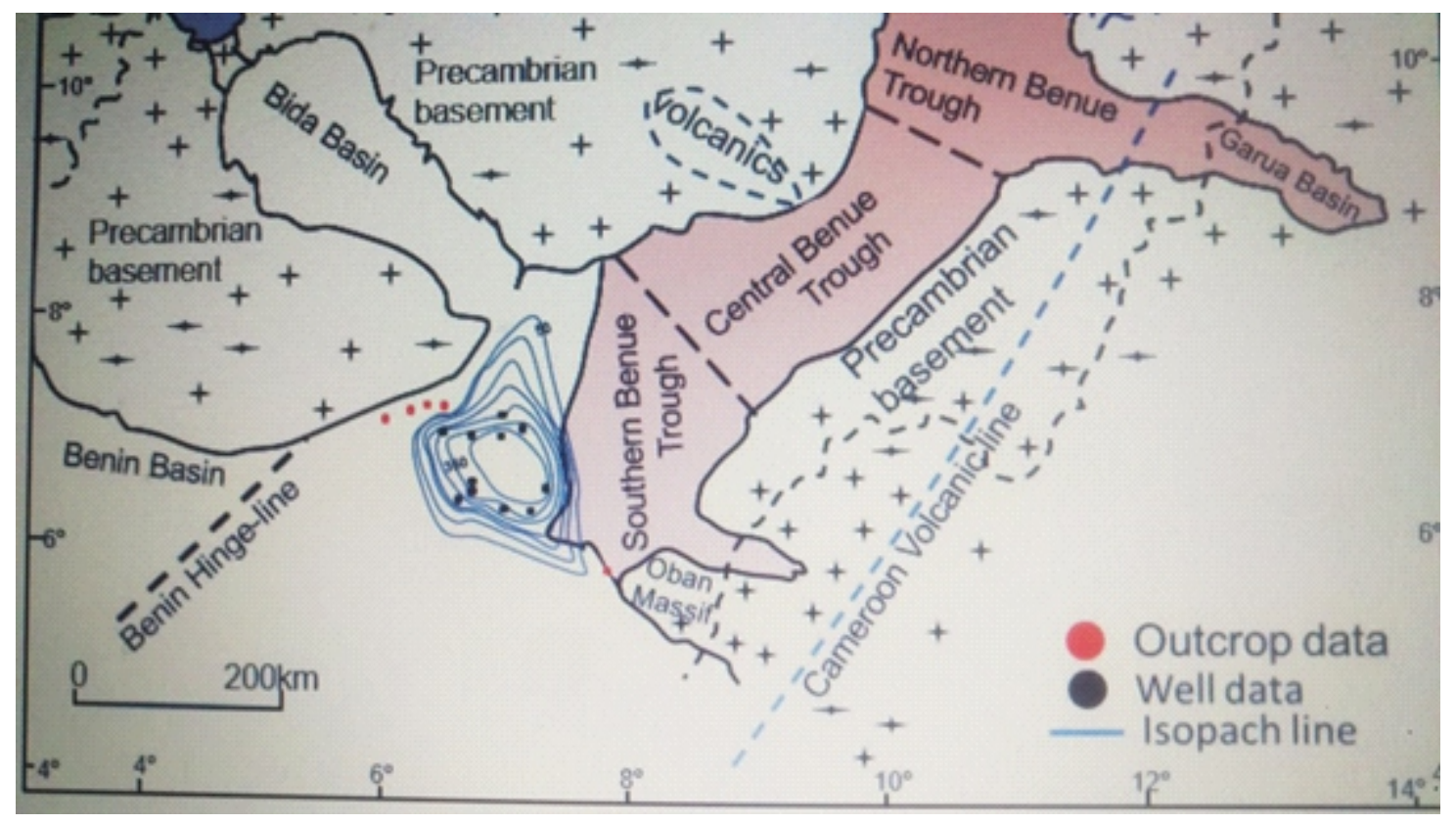

Fig. 5: Isopach map of the Ajali Formation (contour interval $=50 \mathrm{~m}$ ). Modified from Edegbai et al., (2019) 
Table 5: Compositional and textural maturity of sandstone studied

\begin{tabular}{|c|c|c|c|c|c|c|}
\hline $\begin{array}{l}\text { Sample } \\
\text { ID }\end{array}$ & $\begin{array}{l}\text { Quartz } \\
\text { (Grain type) }\end{array}$ & Angular boundary & $\begin{array}{l}\text { Number } \\
\text { of count }\end{array}$ & $\begin{array}{l}\text { Ratio of } \\
\text { Polycrystalline to } \\
\text { Monocrystalline }\end{array}$ & $\begin{array}{l}\text { Textual } \\
\text { maturity }\end{array}$ & $\begin{array}{l}\text { Compositional } \\
\text { maturity }\end{array}$ \\
\hline FG2 & $\begin{array}{l}\text { Polycrystalline } \\
\text { Monocrystalline }\end{array}$ & $\begin{array}{l}\text { Angular to sub - } \\
\text { angular Rounded to } \\
\text { sub-rounded }\end{array}$ & $\begin{array}{l}55 \\
42\end{array}$ & $55: 42$ & Mature & $\begin{array}{l}\text { Mature } \\
(=90 \% \mathrm{Qtz})\end{array}$ \\
\hline FG10 & $\begin{array}{l}\text { Polycrystalline } \\
\text { Monocrystalline }\end{array}$ & $\begin{array}{l}\text { Angular to sub - } \\
\text { angular Rounded to } \\
\text { sub-rounded }\end{array}$ & $\begin{array}{l}57 \\
49\end{array}$ & $57: 49$ & Mature & $\begin{array}{l}\text { Mature } \\
(=90 \% \mathrm{Qtz})\end{array}$ \\
\hline FG16 & $\begin{array}{l}\text { Polycrystalline } \\
\text { Monocrystalline }\end{array}$ & $\begin{array}{l}\text { Angular to sub - } \\
\text { angular Rounded to } \\
\text { sub-rounded }\end{array}$ & 61 & $61: 50$ & Mature & $\begin{array}{l}\text { Mature } \\
(=91 \% \mathrm{Qtz})\end{array}$ \\
\hline FGB3 & $\begin{array}{l}\text { Polycrystalline } \\
\text { Monocrystalline }\end{array}$ & $\begin{array}{l}\text { Angular to sub - } \\
\text { angular Rounded to } \\
\text { sub-rounded }\end{array}$ & $\begin{array}{l}50 \\
52 \\
46\end{array}$ & $52: 46$ & Mature & $\begin{array}{l}\text { Mature } \\
(=89 \% \mathrm{Qtz})\end{array}$ \\
\hline FGB7 & $\begin{array}{l}\text { Polycrystalline } \\
\text { Monocrystalline }\end{array}$ & $\begin{array}{l}\text { Angular to sub - } \\
\text { angular Rounded to } \\
\text { sub-rounded }\end{array}$ & $\begin{array}{l}59 \\
50\end{array}$ & $59: 50$ & Mature & $\begin{array}{l}\text { Mature } \\
(=91 \% \mathrm{Qtz})\end{array}$ \\
\hline FGB12 & $\begin{array}{l}\text { Polycrystalline } \\
\text { Monocrystalline }\end{array}$ & $\begin{array}{l}\text { Angular to sub - } \\
\text { angular Rounded to } \\
\text { sub-rounded }\end{array}$ & $\begin{array}{l}60 \\
45\end{array}$ & $60: 45$ & Mature & $\begin{array}{l}\text { Mature } \\
(=92 \% \mathrm{Qtz})\end{array}$ \\
\hline UZ1 & $\begin{array}{l}\text { Polycrystalline } \\
\text { Monocrystalline }\end{array}$ & $\begin{array}{l}\text { Angular to sub - } \\
\text { angular Rounded to } \\
\text { sub-rounded }\end{array}$ & $\begin{array}{l}61 \\
52\end{array}$ & $61: 52$ & Mature & $\begin{array}{l}\text { Mature } \\
(=90 \% \text { Qtz })\end{array}$ \\
\hline UZ3 & $\begin{array}{l}\text { Polycrystalline } \\
\text { Monocrystalline }\end{array}$ & $\begin{array}{l}\text { Angular to sub - } \\
\text { angular Rounded to } \\
\text { sub-rounded }\end{array}$ & $\begin{array}{l}58 \\
41\end{array}$ & $58: 41$ & Mature & $\begin{array}{l}\text { Mature } \\
(=91 \% \mathrm{Qtz})\end{array}$ \\
\hline UZ5 & $\begin{array}{l}\text { Polycrystalline } \\
\text { Monocrytalline }\end{array}$ & $\begin{array}{l}\text { Angular to sub - } \\
\text { angular Rounded to } \\
\text { sub-rounded }\end{array}$ & $\begin{array}{l}60 \\
51\end{array}$ & $60: 51$ & Mature & $\begin{array}{l}\text { Mature } \\
(=90 \% \mathrm{Qtz})\end{array}$ \\
\hline AY1 & $\begin{array}{l}\text { Polycrystalline } \\
\text { Monocrystalline }\end{array}$ & $\begin{array}{l}\text { Angular to sub - } \\
\text { angular Rounded to } \\
\text { sub-rounded }\end{array}$ & $\begin{array}{l}59 \\
43\end{array}$ & $59: 43$ & Immature & $\begin{array}{l}\text { Mature } \\
(=90 \% \mathrm{Qtz})\end{array}$ \\
\hline AY5 & $\begin{array}{l}\text { Polycrystalline } \\
\text { Monocrystalline }\end{array}$ & $\begin{array}{l}\text { Angular to sub - } \\
\text { angular Rounded to } \\
\text { sub-rounded }\end{array}$ & $\begin{array}{l}60 \\
47\end{array}$ & $60: 47$ & Mature & $\begin{array}{l}\text { Mature } \\
(=90 \% \text { Qts })\end{array}$ \\
\hline AY9 & $\begin{array}{l}\text { Polycrystalline } \\
\text { Monocrystalline }\end{array}$ & $\begin{array}{l}\text { Angular to sub - } \\
\text { angular Rounded to } \\
\text { sub-rounded }\end{array}$ & $\begin{array}{l}63 \\
45\end{array}$ & $63: 45$ & Immature & $\begin{array}{l}\text { Mature } \\
(=91 \% \text { Qtz })\end{array}$ \\
\hline AU1 & $\begin{array}{l}\text { Polycrystalline } \\
\text { Monocrystalline }\end{array}$ & $\begin{array}{l}\text { Angular to sub - } \\
\text { angular Rounded to } \\
\text { sub-rounded }\end{array}$ & $\begin{array}{l}53 \\
44\end{array}$ & $53: 44$ & Immature & $\begin{array}{l}\text { Mature } \\
(=91 \% \text { Qtz })\end{array}$ \\
\hline AU4 & $\begin{array}{l}\text { Polycrystalline } \\
\text { Monocrystalline }\end{array}$ & $\begin{array}{l}\text { Angular to sub - } \\
\text { angular Rounded to } \\
\text { sub-rounded }\end{array}$ & $\begin{array}{l}61 \\
49\end{array}$ & $61: 49$ & Mature & $\begin{array}{l}\text { Mature } \\
(=90 \% \mathrm{Qtz})\end{array}$ \\
\hline AU6 & $\begin{array}{l}\text { Polycrystalline } \\
\text { Monocrystalline }\end{array}$ & $\begin{array}{l}\text { Angular to sub - } \\
\text { angular Rounded to } \\
\text { sub-rounded }\end{array}$ & $\begin{array}{l}54 \\
46\end{array}$ & $54: 46$ & Immature & $\begin{array}{l}\text { Mature } \\
(=90 \% \mathrm{Qtz})\end{array}$ \\
\hline
\end{tabular}



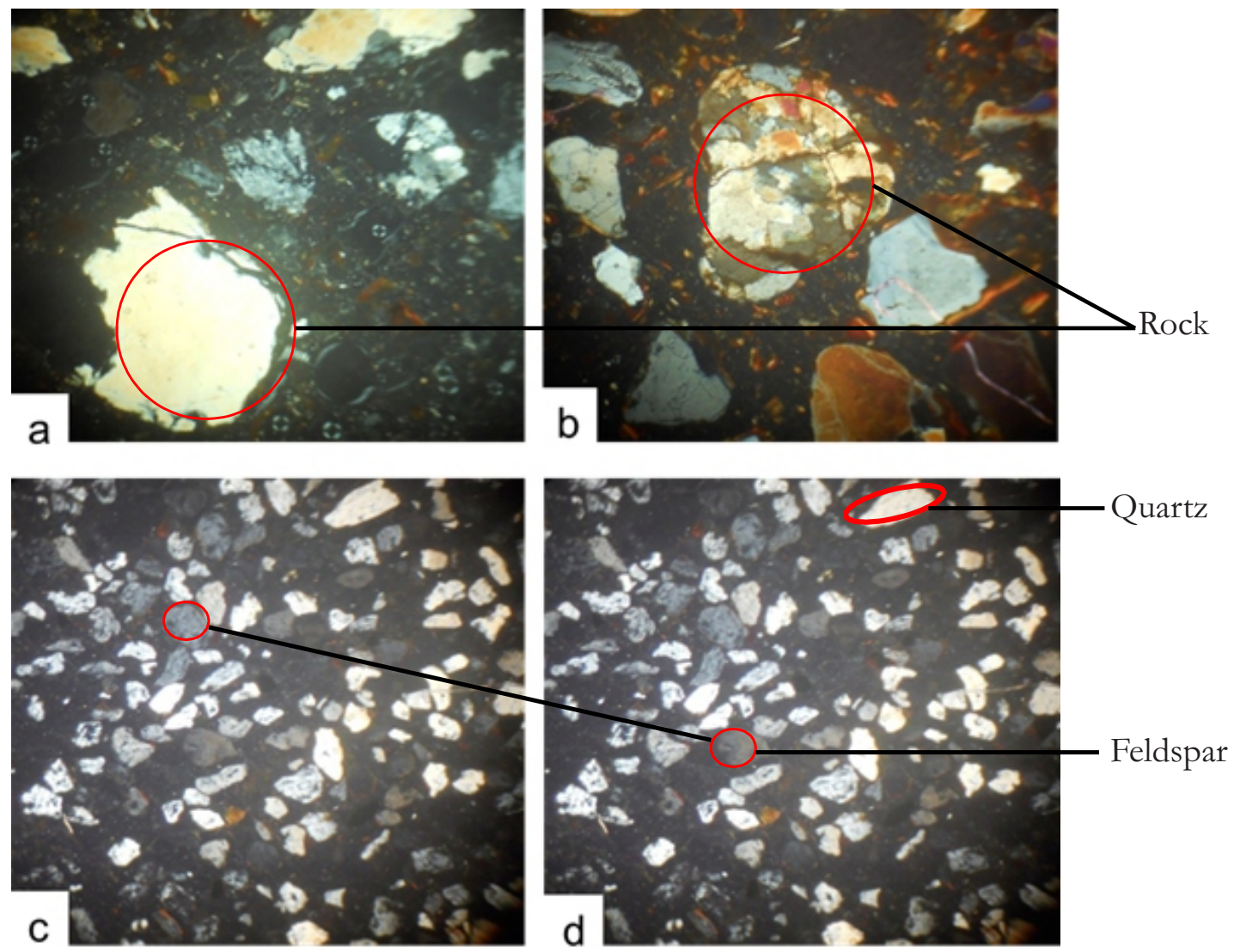

Plate 1: Photo micrograph of Sandstone at Fugar, Ayogwuiri, Auchi and Uzebba from thin section analysis under cross polarized light (30x).
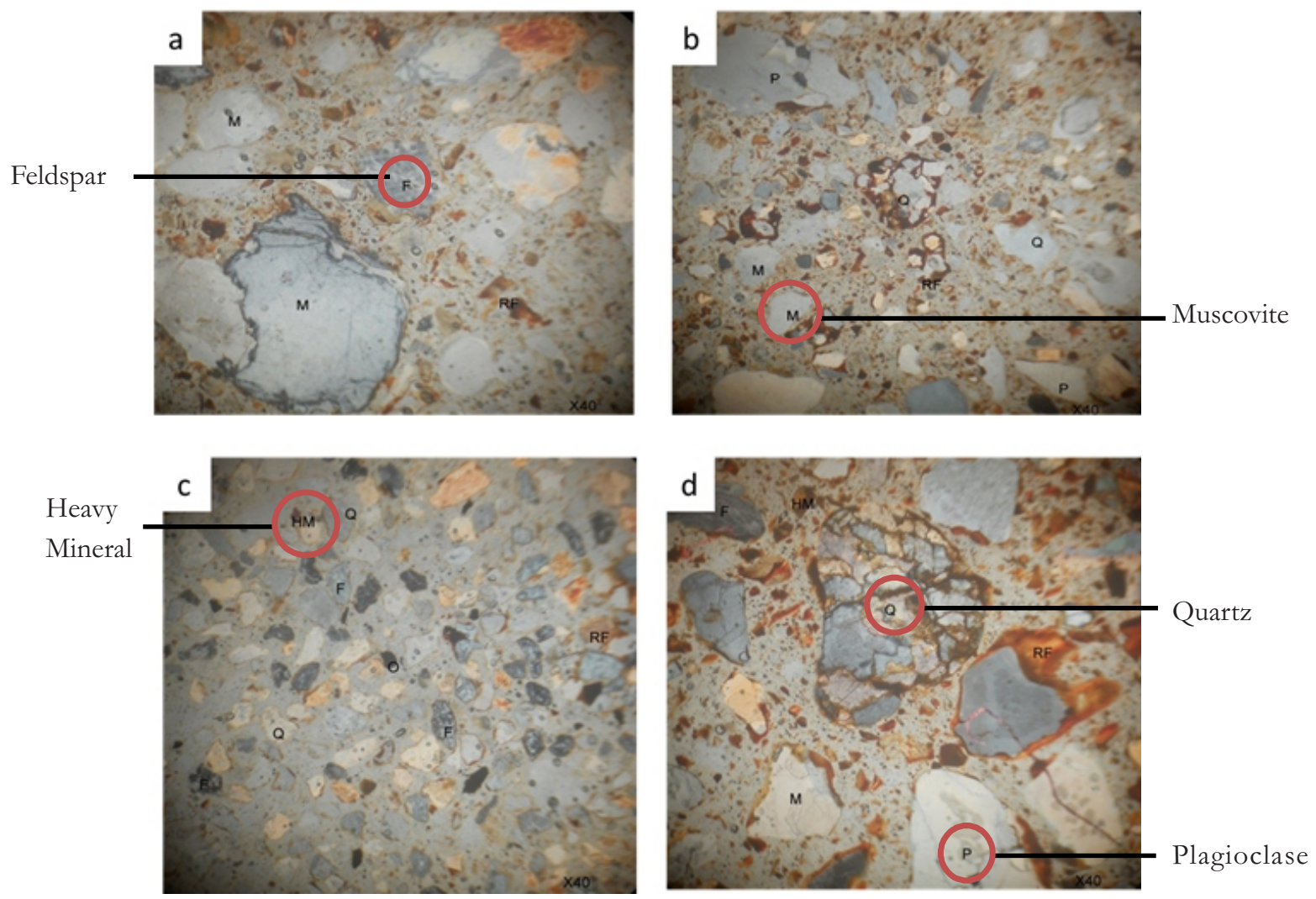

Plate 2. Photo micrograph of Fugar, Ayogwuiri, Auchi and Uzebba sands (a, b, c, d, respectively) from thin section analysis under plane polarized light (30x). M - Muscovite, RF- Rock fragments, Q - Quartz, HM - Heavy mineral, F-Feldspar, PPlagioclase 
Table 6: Heavy minerals and Zircon Tourmaline Rutile (ZTR) index.

ZTR index $=\mathrm{Z}+\mathrm{R}+\mathrm{T} /$ Total non - Opaque $* 100$

\begin{tabular}{|c|c|c|c|c|c|c|c|c|}
\hline SAMPLE ID & ZIRCON & RUTILE & TOUMALINE & STAUROLITE & GARNET & KYANITE & OPAQUE & ZTR INDEX \\
\hline FG2 & 6 & 6 & 7 & 5 & 3 & 4 & 24 & 61.29 \\
\hline FG10 & 7 & 5 & 7 & 4 & 2 & 4 & 23 & 65.52 \\
\hline FG16 & 8 & 6 & 8 & 6 & 5 & 2 & 28 & 62.86 \\
\hline FGB3 & 8 & 5 & 6 & 4 & 3 & 2 & 29 & 67.86 \\
\hline FGB7 & 9 & 8 & 4 & 5 & 3 & 4 & 28 & 63.64 \\
\hline FGB12 & 6 & 7 & 8 & 6 & 5 & 3 & 30 & 60.0 \\
\hline FG7 & 7 & 6 & 6 & 4 & 3 & 3 & 25 & 65.52 \\
\hline FG13 & 8 & 6 & 5 & 4 & 2 & 4 & 27 & 65.52 \\
\hline FGB10 & 8 & 6 & 9 & 5 & 3 & 3 & 28 & 67.65 \\
\hline FGB5 & 7 & 7 & 9 & 6 & 2 & 2 & 29 & 69.70 \\
\hline UZ1 & 5 & 6 & 7 & 4 & 2 & 1 & 27 & 72.0 \\
\hline UZ3 & 7 & 5 & 6 & 3 & 4 & 3 & 26 & 64.29 \\
\hline UZ5 & 5 & 6 & 5 & 4 & 4 & 5 & 29 & 55.17 \\
\hline UZ2 & 6 & 7 & 5 & 3 & 5 & 2 & 28 & 64.29 \\
\hline UZ4 & 7 & 7 & 5 & 5 & 4 & 4 & 26 & 59.38 \\
\hline AY1 & 9 & 8 & 10 & 4 & 3 & 3 & 29 & 72.97 \\
\hline AY5 & 8 & 6 & 7 & 5 & 4 & 2 & 30 & 65.63 \\
\hline AY9 & 9 & 5 & 8 & 4 & 2 & 2 & 27 & 73.33 \\
\hline AY4 & 10 & 6 & 8 & 3 & 4 & 2 & 29 & 72.73 \\
\hline AY7 & 8 & 8 & 9 & 6 & 4 & 2 & 26 & 67.57 \\
\hline AU1 & 6 & 5 & 7 & 4 & 3 & 3 & 26 & 64.29 \\
\hline $\mathrm{AU} 4$ & 7 & 5 & 6 & 5 & 4 & 1 & 25 & 64.29 \\
\hline AU6 & 8 & 6 & 4 & 3 & 2 & 3 & 27 & 69.23 \\
\hline AU2 & 7 & 7 & 8 & 4 & 3 & 4 & 28 & 66.67 \\
\hline AU5 & 8 & 7 & 6 & 5 & 4 & 3 & 26 & 63.64 \\
\hline
\end{tabular}
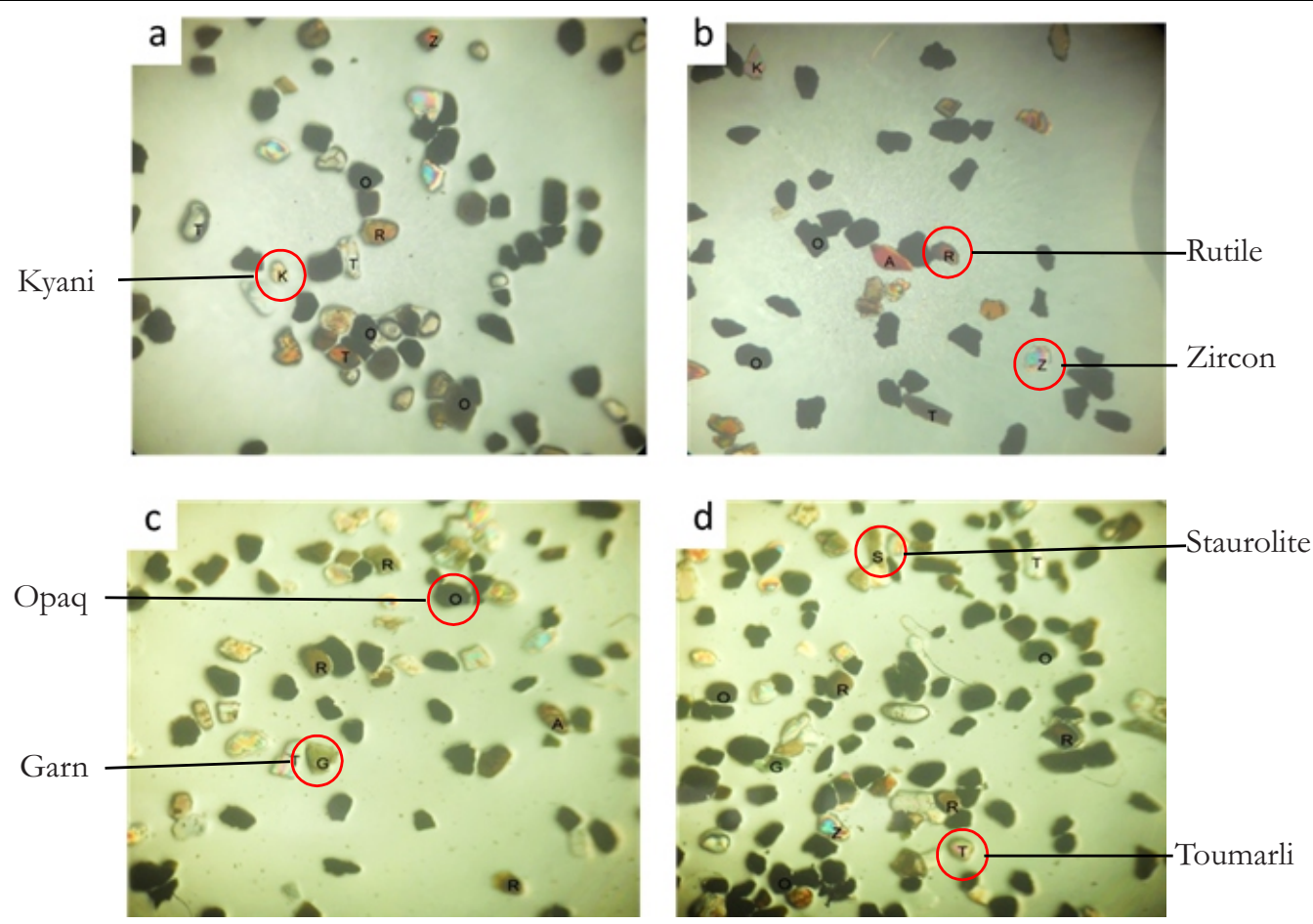

Plate 3: Photo micrograph of Heavy minerals analysis of Sandstone at Fugar, Ayowuiri, Auchi and Uzebba (a, b, c, d, respectively) under plane polarized light (30x). $\mathrm{Z}=$ Zircon, $\mathrm{R}=$ Rutile, $\mathrm{T}=$ Toumaline, $\mathrm{G}=$ Garnet, $\mathrm{S}=$ Staurolite, $\mathrm{K}=$ Kyanite, $\mathrm{O}=$ Opaque 

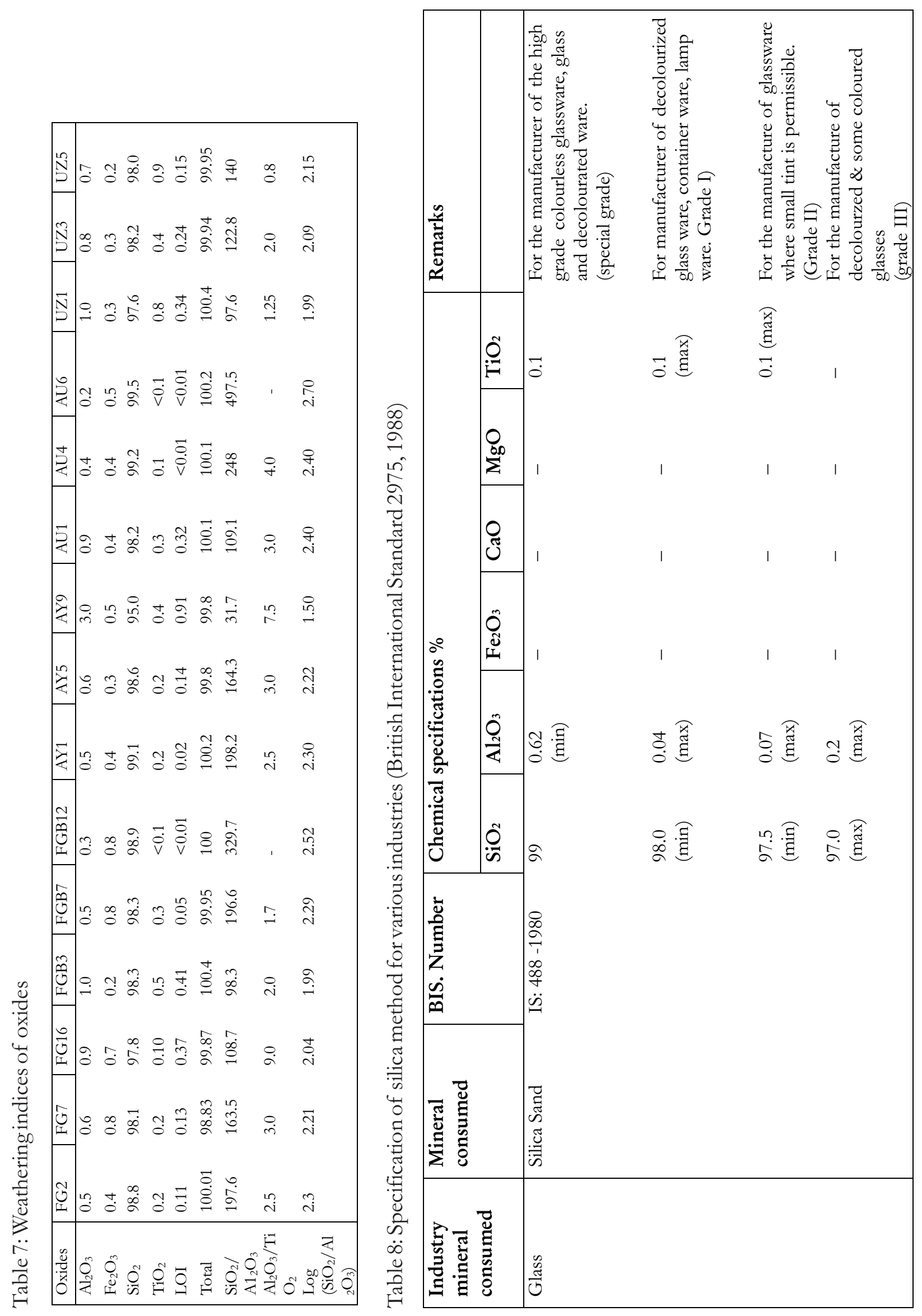


\section{CONCLUSION}

Based on the textural and geochemical characteristics studied for the sandstone of Ajali Formation, western flank, Anambra Basin, the mean $\mathrm{SiO}_{2} / \mathrm{Al}_{2} \mathrm{O}_{3}$ ratio of 180.24 , mineralogical maturity index (MMI) of 17.4 both indicate mineralogically matured sediments while a Zircon - Tourmaline - Rutile (ZTR) index of $67.96 \%$, indicate a chemically immature to sub - mature sandstone. The weathering index, the mineralogical maturity index, textural characteristics and modal composition of the sandstone all points to a textural, compositional and mineralogically matured sandstone. The mineralogical maturity of the Ajali Sandstone is an indication that the source area weathering was very high. The volumetric together with the textural and geochemical characteristics of the Ajali Sandstone is an indication that the formation maybe considered for economic exploration and exploitation activities of the resources within the Basin.

\section{ACKNOWLEDGEMENT}

We acknowledge the support received from the field assistants Dr. Joel A. Edegbai and Dr. Marvellous Omoregieva during the cause of this study. We sincerely and warmly appreciate the Laboratory Technologists, Mr. V.O. Binitie and Mr. Omoruyi, of the Department of Geology, University of Benin for the assistance rendered during the study. We appreciate Mr. and Mrs. N.G Ilevbare, Mr. Ikhoshuo Andrew and Mrs. C. Elusoji for their financial support. Thanks to Mr. Mike Uwagbai of blessed memories and Mr. Hope Omodolor for reading the manuscript.

\section{REFERENCES}

Akpofure, E. and Akana, S.T. (2019). Grain size Analysis of Beach Sediments from Bonny Beach in the Niger Delta. International Journal of Geology and Mining, 5(2):245257.

Akpofure, E. and Etu-Efeotor J.O. (2013). Petrography of Ajali Sandstone in Ayogwuiri - Fugar-Orame area of Western Anambra Basin: Implication for Digenetic depositional History. Journal of environment and earth sciences, 3(5), 104 $-113$.
Adekoya, J.A., A.F. Aluko and S.A. Opeloye, (2011). Sedimentological characteristics of ajali sandstone in the Auchi environs of Anambra basin, Nigeria. Ife J. Sci., 13(2): 52-67.

Akaegbobi, E and Adeleye, O. (2001). Diagenesis and its implication on the Reservoir quality of parts of Ajali Sandstone in Cretaceous Anambra Basin, Southern Nigeria. AAPG annual meeting, demure Cororado. June 3-6.

Amajor, L.C. (1987), paleocurrent, petrography and provenance analysis of the Ajali sandstone (upper cretaceous), Southern Benue Trough, Nigeria. Sedimentary Geology. 54: 47-60.

Anithamary, I., Ramkumar, T. and Venkatramanan, S. (2011). Grain size characteristics of the coleroon estuary sediments, Tamilnadu, east coast of India. Carpathian J Earth Environ Sci 6(2), pp. 151-157.

Baruah, J., Kotoky, P. and Samma, J. (1997). Textural and geochemical study on river sediments: a case study on the Jhanji River, Assam. J. Indian Assoc. Sedimental. 16: 195-206.

British International Standard 2975: 1988. Methods of sampling and analysis of glass making sands.

Dora, G.U., Kumar, V.S., Philip C.S., Johnson, G., Vinayaraj., P and Gowthaman, R., (2011). Textural characteristics of foreshore sediments along Karnataka Shoreline, West coast of India. International Journal of Sediment Research, 26(3):364377.

Edegbai, A.J., Schwark, L., Oboh-Ikuenobe, F.E., 2019b. Campano-Maastrichtian paleoenvironment, paleotectonics and sediment provenance of Western Anambra Basin, Nigeria: Multi-proxy evidences from the Mamu Formation. https://doi.org/10.1016/j.jafrearsci.201 9.04.001

Folk, R.L. (1965). Petrology of Sedimentary Rocks. Austin, University of Texas Publication, 170

Friedman, G.M., (1961). Distinction between dune, beach and river sands from the 
textural characteristics: Journal Sedimentary Petrology, 31: 514-529.

Friedman G.M.(1962). On Sorting, sorting coefficient and Log Normality of the grain size distribution of Sandstones. J. Geol.70: $734-753$

Gideon, Y.B, Fatoye F.B. and Omoda, J.I. (2014). Sedimentological characteristics of geochemistry of Ajali sandstone exposed at Northern Anambra Basin, Nigeria. Journal of Environmental and earth science, 6(1),pp. 10-17

Hay, W.W., Floegel, S., 2012. New thoughts about the Cretaceous climate and oceans. Earth Science Revierws, 115, 262-272

Hogue, M. and Ezepue, M.C. (1977). Petrology and paleo-geography of Ajali sandstone. Journal.Min. Geol., 14(1):16-22.

Ladipo, K.O., (1986). Tidal shelf depositional model for the Ajali sandstone, Anambra Basin, Southern Nigeria. Journal African Earth Sciences, 5(2): 177-185.

Manger, M.A. and Maurer, F.W. (1992). Heavy minerals in colour. Chapman \& Hall, London.

Nwajide, C.S. and Hoque, M. (1985). Application of Markov chain and entropy analysis to Lithologic Successions: an example from the Cretaceous of Benue Trough(Nigeria). Geol. Rndsh, 74: 165177.

Odumoso, S.E., Olotu, I.N. and Omoboriowo, A.O. (2013). Sedimentology and depositional environment of the midMaastrichtian Ajali Sandstone, Anambra Basin, Southern Nigeria. International Journal of Science and Technology, 3(1): 26-32.

Potter, P.E. (1978). Petrology and chemistry of modern River sands. The Journal of Geology, 86(4): 423-449.

Ramanathan, A.L., Rajkumar, K., Majumdar, J., Singh, G., Behera, P.N., Santra, S.C. and Chidambaram, S. (2009). Textural characteristics of the surface sediments of a tropical mangrove Sundarban ecosystem, India. Indian J Mar Sci, 38(4): 397-403.

Ray, A.K., Tripathy, S.C., Patra. S., Samma, V.V (2006). Assesement of Godquari estuarine mangrove ecosystem through trace metal studies. Environ. Int. 32: 219223.

Reijers, T.J.A., Petters, S.W., Nwajide, C.S., 1997. The Niger Delta Basin. In: Selley, R.C. (Ed.), African Basins. Elsevier, Amsterdam, p. 151-172

Sutherland, R.L.C (1994). Discrimination between coastal sub-environs using textural characteristics. Sedimentology 11: 1133-1114.

Total Nigeria Limited (1988): OPL 447 Anambra river field - Evaluation - quick look du gistment (unpublished article), 6265. 